\title{
Growth, Quality Index, and Mineral Composition of Five Ornamental Cabbage Cultivars Grown Under Different Nitrogen Fertilization Rates
}

\author{
Mariateresa Cardarelli \\ Consiglio per la Ricerca in Agricoltura e l'Analisi dell'Economia Agraria, \\ Centro di Ricerca per lo Studio delle Relazioni tra Pianta e Suolo, Via della \\ Navicella 2-4, 00184 Roma, Italy
}

Youssef Rouphael

Department of Agricultural Sciences, University of Naples Federico II, 80055 Portici, Italy

\author{
Delia Muntean \\ "Ion Ionescu de la Brad" University of Agricultural Sciences and Veterinary \\ Medicine of IASI, Aleea Mihail Sadovean 3, Iasi, 700490, Romania
}

Giuseppe Colla ${ }^{1}$

Department of Agriculture, Forestry, Nature and Energy, University of Tuscia, via San Camillo De Lellis snc, 01100 Viterbo, Italy

Additional index words. Brassica oleraccea L. var. acephala D.C., $\mathrm{F}_{\mathrm{v}} / \mathrm{F}_{\mathrm{m}}$, hydroponics, nitrate concentration, NUE, SPAD index

\begin{abstract}
The fertilizer nitrogen (N) inputs to some potted plants such as ornamental cabbage (Brassica oleracea $\mathrm{L}$. var. acephala D.C.) are frequently higher than the actual demand. Optimization of $\mathbf{N}$ fertilization rate and selecting $\mathbf{N}$-efficient cultivars are important approaches to increase the nitrogen use efficiency (NUE) and to reduce environmental pollution from nitrate leaching. The aim of this study was to assess the effect of increasing levels of nitrate $\left(0.5,2.5,5,10\right.$, or $\left.20 \mathrm{~mm} \mathrm{of} \mathrm{NO}_{3}{ }^{-}\right)$in the nutrient solution on plant growth, quality, soil plant analysis development (SPAD) index, chlorophyll fluorescence, leaf pigments, mineral composition, and NUE in five ornamental cabbage cultivars (Coral Prince, Coral Queen, Glamour Red, Northern Lights Red, and White Peacock), grown in closed subirrigation system. 'Glamour Red' and

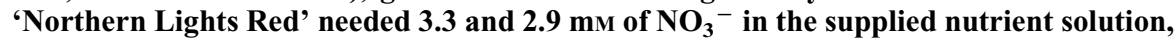
respectively, to produce $50 \%$ of predicted maximum shoot dry weight (SDW), whereas the vigorous cultivars Coral Prince, Coral Queen, and White Peacock needed 5.5, 4.7, and $4.3 \mathrm{~mm}$ of $\mathrm{NO}_{3}{ }^{-}$, respectively. Total leaf area (LA), SDW, SPAD index, N, Ca, and $\mathrm{Mg}$ concentrations increased linearly and quadratically in response to an increase of the nitrate concentration in the nutrient solution. Irrespective of cultivars, fertilizing above $10 \mathrm{mM} \mathrm{NO}_{3}{ }^{-}$produced high-quality plants (quality index of 5) and resulted in sufficiently high tissue concentrations of $\mathrm{N}, \mathrm{P}, \mathrm{K}, \mathrm{Ca}, \mathrm{Mg}$, and Fe.
\end{abstract}

Ornamental cabbage (Brassica oleracea L. var. acephala D.C.) is a common potted bedding plant all over the World. The ornamental cabbage aesthetic value in particular its attractive colored foliage, make it a very popular annual in the home landscape, especially in the fall and early winter seasons when other plants are senescing (Kushad et al., 2004). To produce high-quality ornamental plants, nutritional requirements especially $\mathrm{N}$ must be established. Nitrogen-nitrate

Received for publication 23 Jan. 2015. Accepted for publication 24 Feb. 2015.

We are grateful to Stefano Lazzaretti for the help in data collection.

${ }^{1}$ To whom reprint requests should be addressed; e-mail giucolla@unitus.it. friendly, whereas remaining competitive (MacDonald et al., 2013). Several strategies have been proposed to improve the NUE of crops including the selection of efficient cultivars (Rathke et al., 2006; Roberts, 2008). Optimization of $\mathrm{N}$ application rate is also crucial for commercial ornamental production. In fact, there is a critical $\mathrm{N}$ concentration below which the plants show a limited growth and above which the plant show a luxury consumption leading to environmental pollution and economic losses (Benincasa et al., 2011; Gamrod and Scoggins, 2006; Lemaire and Gastal, 1997). Moreover, different cultivars vary in their $\mathrm{N}$ demands, and consequently they perform best at different $\mathrm{N}$ concentrations (Marschner, 2002). For this reason, the identification of cultivars with high NUE could lead to low environmental impact on agrosystems while maintaining high crop performance (Hirsch and Sussman, 1999; Lynch, 1998; Sorgonà et al., 2006). Gourley et al. (1994) suggested that "a well-defined response curve is needed to determine differences in nutrient efficiency." This approach allowed an estimation of the maximum yield/ growth $(\alpha)$ and the nutrient concentration necessary for half maximum yield/growth ( $\beta$ ). Similar $\alpha$ and different $\beta$ indicate efficient/inefficient cultivars, whereas different $\alpha$ indicates cultivars with lower/higher genetic potential (Gourley et al., 1994). These criteria has been successfully applied in herbaceous species in response to phosphate and potassium availability (Gerendás et al., 2008; Gourley et al., 1994), and also in the evaluation of the genotypic variation in Citrus, melon, and watermelon rootstocks at different nitrate levels (Colla et al., 2010, 2011; Sorgonà et al., 2006).

Despite the importance of ornamental cabbage in floriculture production, few published data are available concerning $\mathrm{N}$ efficiency of ornamental cabbage cultivars (Gibson and Whipker, 2003). Gibson and Whipker (2003) studied the effect of $\mathrm{N}$ concentration in ornamental cabbage $\mathrm{cv}$. Osaka white grown outdoors, and observed that fertilizing with 150 to $200 \mathrm{mg} \cdot \mathrm{L}^{-1}$ produced high-quality plants. However, the response of ornamental cabbage to $\mathrm{N}$ was only investigated on one cultivar and using three concentration levels, whereas information is lacking concerning the influence of different levels of N including "low-input" conditions on different cultivars, especially in soilless culture.

The objective of this study was to assess the effect of increasing levels of nitrate in the nutrient solution on plant growth, quality, SPAD index, chlorophyll fluorescence, leaf pigments, mineral composition, and NUE in five ornamental cabbage cultivars (Coral Prince, Coral Queen, Glamour Red, Northern Lights Red, and White Peacock) grown in closed subirrigation system.

\section{Materials and Methods}

Plant materials, growth conditions, and experimental design. The experiment was 
carried out in Autumn 2012 growing season, in a $300 \mathrm{~m}^{2}$ polyethylene greenhouse situated on the experimental farm of Tuscia University, Central Italy (lat. $42^{\circ} 25^{\prime} \mathrm{N}$, long. $12^{\circ} 08^{\prime} \mathrm{E}$, alt. $310 \mathrm{~m}$ above sea level). Inside the greenhouse the daily temperatures were maintained between 12 and $25^{\circ} \mathrm{C}$.

Five ornamental cabbage (Brassica oleracea L. var. acephala D.C.) cultivars (Coral Prince, Coral Queen, Glamour Red, Northern Lights Red, and White Peacock), purchased from Nickys Nursery Ltd (CT10 2JU, United Kingdom), were transplanted on 19 Sept. into pots (diameter $16 \mathrm{~cm}$, height $14 \mathrm{~cm}$ ) containing $2.5 \mathrm{~L}$ of mixture peat:perlite in a $2: 1$ volume ratio. The pots were placed on 16-cm-wide and 6-m-long troughs, with $30 \mathrm{~cm}$ between pots and $25 \mathrm{~cm}$ between troughs, giving a plant density of 13.3 plants $/ \mathrm{m}^{2}$.

Treatments were arranged in a completely random design with three replicates. Treatments were defined by a split-plot design of five nitrate levels in the nutrient solution ( 0.5 , $2.5,5,10$, or $20 \mathrm{~mm}$ of $\mathrm{NO}_{3}{ }^{-}$) and five ornamental cabbage cultivars previously referenced, amounting to a total of 75 experimental unit plots. Each experimental unit consisted of six plants. Nitrate levels in the nutrient solution were assigned to main plots, whereas cultivars to subplots.

Nutrient solution management. The composition of the nutrient solution used in the current experiment was: $1.0 \mathrm{~mm}$ P, $2.75 \mathrm{~mm}$ $\mathrm{S}, 4.0 \mathrm{~mm} \mathrm{~K}, 1.25 \mathrm{~mm} \mathrm{Mg}, 20 \mu \mathrm{M} \mathrm{Fe}, 9 \mu \mathrm{M}$ $\mathrm{Mn}, 0.3 \mu \mathrm{M} \mathrm{Cu}, 1.6 \mu \mathrm{M} \mathrm{Zn}, 20 \mu \mathrm{M} \mathrm{B}$, and $0.3 \mu \mathrm{M}$ Mo. Calcium nitrate was added to the nutrient solution to obtain the five nitrate levels $(0.5,2.5,5,10$, or $20 \mathrm{~mm})$ tested or the five ornamental cabbage cultivars. Furthermore, calcium sulfate was added to the nutrient solution to keep $\mathrm{Ca}$ concentration above $5 \mathrm{~mm}$. The $\mathrm{pH}$ of the nutrient solution for all treatments was $6.0 \pm 0.2$. All nutrient solutions were prepared using deionized water. In all treatments nutrient solution was changed once a week to ensure sufficient nutrient for plant growth and to keep nitrate level in solution close to the targeted level.

Nutrient solution was pumped from 15 independent tanks (one tank of $30 \mathrm{~L}$ per experimental unit) through a subirrigation system. In the subirrigation system the nutrient solution was pumped at the elevated end of the troughs and allowed to run slowly down the bench past the pots, and the excess was drained back to the tank for later recirculation. Irrigation scheduling was performed using electronic low-tension (LT) tensiometers (LT-Irrometer, Riverside, CA) that controlled irrigation based on substratematric potential (Norrie et al., 1994). Tensiometers have been placed at about the midpoint of the pots $(\approx 7 \mathrm{~cm}$ depth $)$ (Rouphael and Colla, 2005a, 2005b). In each treatment, three tensiometers were installed, and there were located in different pots to provide a representative reading of the moisture tension. Tensiometers were connected to an electronic programmer that controlled the beginning $(-5 \mathrm{kPa})$ and end $(-1 \mathrm{kPa})$ of irrigation, which correspond to the highand low-tension set points for the major part of the media (Rouphael et al., 2004). The timing varied from one to six fertigations per day lasting 20-30 min.

Recording, sampling, and analysis. Eightytwo days after transplanting (12 Dec.), a chlorophyll meter (SPAD-502, Minolta corporation, Ltd., Osaka, Japan) was used to take readings from the fully expanded leaves. Twenty leaves per experimental unit were randomly measured and averaged to a single SPAD value for each treatment. On the same date, the chlorophyll fluorescence was recorded on 15 min dark-adapted leaves on six plants per experimental unit (five leaves per plant) by means of a chlorophyll fluorometer Handy PEA (Hansatech Instruments Ltd, King's Lynn, UK) with an excitation source intensity higher than 3000 $\mu \mathrm{mol} \cdot \mathrm{m}^{-2} \cdot \mathrm{s}^{-1}$ at the sample surface. The minimal fluorescence intensity $\left(\mathrm{F}_{0}\right)$ in a darkadapted state was measured in the presence of a background weak light signal $(\approx 2-3 \mu \mathrm{mol}$ photons $\left.\cdot \mathrm{m}^{-2} \cdot \mathrm{s}^{-1}\right)$. The maximal fluorescence level in the dark-adapted state $\left(\mathrm{F}_{\mathrm{m}}\right)$ was induced by $0.8 \mathrm{~s}$ saturating light pulse $\left(3000 \mu \mathrm{mol}\right.$ photons $\left.\cdot \mathrm{m}^{-2} \cdot \mathrm{s}^{-1}\right)$. The maximum quantum yield of open photosystem II (PSII) $\left(\mathrm{F}_{\mathrm{v}} / \mathrm{F}_{\mathrm{m}}\right)$ was calculated as $\left(\mathrm{F}_{\mathrm{m}}-\mathrm{F}_{0}\right) / \mathrm{F}_{\mathrm{m}}$, as described by Arena et al. (2005).

The leaf pigments (total chlorophyll and carotenoids) were extracted by homogenization of fresh leaf tissues $(0.5 \mathrm{~g})$ in acetone $(80 \%)$. The resulting extracts were centrifuged at $4800 g_{\mathrm{n}}$ for $20 \mathrm{~min}$. The total chlorophyll and carotenoid contents were determined by recording absorbance of the supernatant at 470,647, and $664 \mathrm{~nm}$ by an ultraviolet-Vis spectrophotometer (Perkin Elmer, Norwalk, CT). Formula and extinction coefficients used for the determination of leaf pigments were described by Lichtenhaler and Wellburn (1983) and the content of pigments was expressed in $\mu \mathrm{g} \cdot \mathrm{g}^{-1}$ of fresh weight.

At the end of the experiment, $90 \mathrm{~d}$ after transplanting (20 Dec.), plant quality index was rated on a scale of 0 to 5 . Plant height and plant diameters were also recorded. Height $(\mathrm{H})$ was measured as the distance from the surface of the medium to the top of the plant, width (diameter, W) as the average of two measurements, one perpendicular to the other. Plant growth index (GI) was calculated as:

$$
G I=\pi\left(\frac{W}{2}\right)^{2} H
$$

The shoot tissues of six plants per plot were dried in a forced-air oven at $80{ }^{\circ} \mathrm{C}$ for $72 \mathrm{~h}$ for biomass determination. Total leaf area (LA) was measured with an electronic area meter (Delta-T Devices Ltd, Cambridge, UK). SDW was plotted as a function of the different nitrate concentrations. Response curves for growth were derived from the relationship between the SDW and the nitrate concentrations in the nutrient solution using the following Michaelis-Menten type equation (Gourley et al., 1994):

$$
y=\frac{\alpha x}{\beta+x}
$$

where $y$ indicates the SDW (grams/plant), $x$ is the nitrate concentration (mM) and; $\alpha$ is an estimate of maximum SDW, whereas $\beta$ represents the nitrate concentration necessary for half maximum SDW.

The dried leaf tissues were ground in a Wiley mill to pass through a 20-mesh screen and then $0.5 \mathrm{~g}$ of the dried plant tissues were analyzed for the following macro- and micronutrients: $\mathrm{N}, \mathrm{P}, \mathrm{K}, \mathrm{Ca}, \mathrm{Mg}$, and $\mathrm{Fe} . \mathrm{N}$ concentration was determined after mineralization with sulphuric acid according to the "Kjeldahl method" (Bremner, 1965). P, K, $\mathrm{Ca}, \mathrm{Mg}$, and $\mathrm{Fe}$ concentrations were determined by dry ashing at $400{ }^{\circ} \mathrm{C}$ for $24 \mathrm{~h}$, dissolving the ash in 1:25 HCl, and assaying the solution obtained using an inductively coupled plasma emission spectrophotometer (ICP Iris; Thermo Optek, Milano, Italy) (Karla, 1998). The macronutrients were expressed as $\mathrm{mg} \cdot \mathrm{g}^{-1}$ dry weight, whereas Fe was reported as $\mu \mathrm{g} \cdot \mathrm{g}^{-1}$ dry weight.

Statistical analysis. Analysis of variance of the data was carried out using the appropriate options within SPSS 20 software package (www.ibm.com/ software/analytics/spss). Orthogonal polynomial contrasts were used to compare $\mathrm{N}$ fertilization effects (Gomez and Gomez, 1983) on selected parameters. The parameters $\alpha$ and $\beta$ of the MichaelisMenten type equation were estimated by the "least square" method of nonlinear regression using SigmaPlot version 11.0 (Systat Software, Inc., Chicago, IL)

\section{Results}

Effect of $N$ concentration on biomass response curves. In the current experiment, the Michaelis-Menten equation was used to describe the functional relationships between total SDW and nitrate concentrations in the nutrient solutions (Fig. 1). This nonlinear equation has been adopted because the coefficients of this function can be interpreted in a simple and straight-forward fashion, unlike those of polynomials. In analogy to the enzyme kinetics the nitrate concentration required to produce $50 \%$ of the predicted SDW $(\beta)$ corresponds to $K_{m}$ in MichaelisMenten kinetics and usually describes the curvature of the graph. Therefore, $\beta$ is considered a good indicator of the sensitivity of a species/cultivars to reduced nutrient supply.

Except for 'Glamour Red', SDW response curves of 'Coral Prince', 'Coral Queen', 'Northern Lights Red', and 'White Peacock' produced a coefficient of determination $\left(R^{2}\right)$ greater than 0.95 (Table 1). Significant differences among ornamental cabbage cultivars were recorded on $\alpha$ values with the lowest values observed in both 'Glamour Red' and 'Northern Lights Red' (average $10.7 \mathrm{~g} /$ plant). Similarly, $\beta$ values were significantly influenced by cultivars 


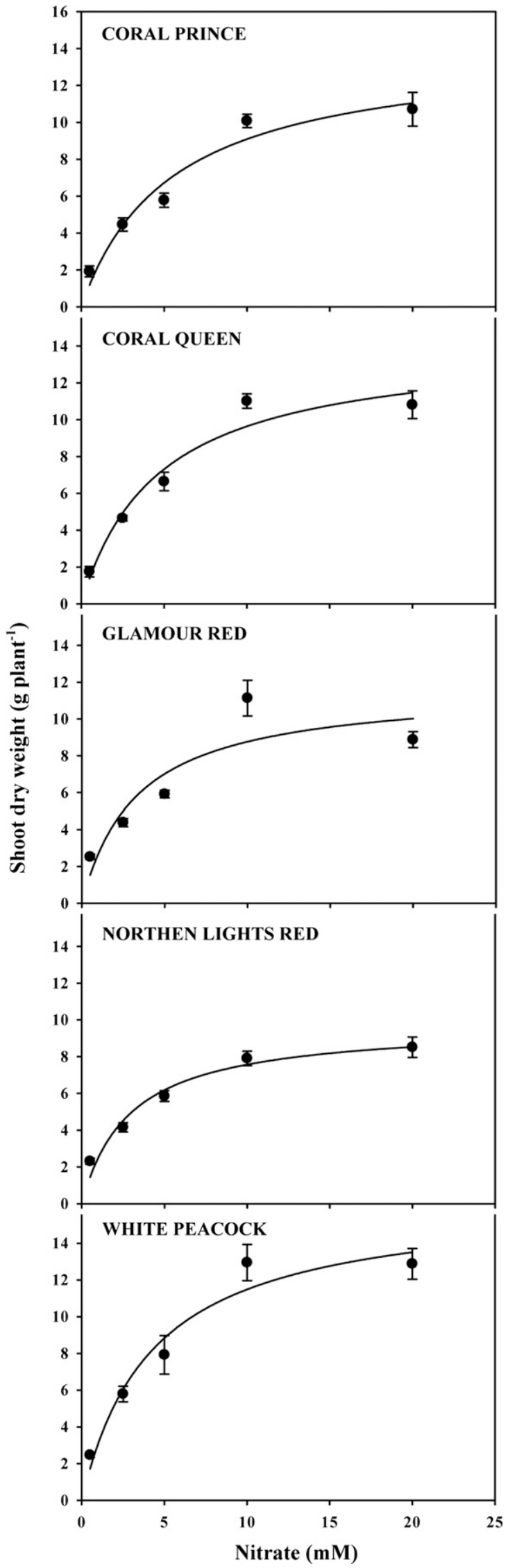

Fig. 1. Shoot dry weight (SDW) response curves $[y=\alpha \mathrm{x} /(\beta+\mathrm{x})]$ of different ornamental cabbage cultivars (Coral Prince, Coral Queen, Glamour Red, Northern Lights Red, and White Peacock) grown over $90 \mathrm{~d}$ with different nitrate concentrations in the nutrient solution $\left(0.5,2.5,5,10\right.$, or $\left.20 \mathrm{mM} \mathrm{NO}_{3}^{-}\right)$, where $y$ indicates the SDW, $x$ is the nitrate concentration, $\alpha$ indicates maximum SDW, whereas $\beta$ represents the nitrate concentration at half maximum SDW. Vertical bars indicate \pm SE of means, their absence indicates the size was less than the symbol. with the lowest value observed in 'Northern Lights Red' (Table 1). Moreover, the less vigorous cultivars (lower $\alpha$ values), Glamour Red and Northern Lights Red, needed 3.3, and $2.9 \mathrm{mM}$ of $\mathrm{NO}_{3}{ }^{-}$, respectively, to produce $50 \%$ of predicted maximum SDW, whereas the vigorous cultivars (higher $\alpha$ values), Coral Prince, Coral Queen, and White Peacock, needed 5.5, 4.7, and $4.3 \mathrm{~mm}$ of $\mathrm{NO}_{3}{ }^{-}$, respectively ( $\beta$ values in Table 1$)$.

Growth and plant quality. Increasing the nitrate concentration in the nutrient solution from 0.5 to $20 \mathrm{~mm}$ caused linear and quadratical increases for the leaf area values, whereas the leaf number increased only linearly (Table 2 ). Moreover, when averaged over $\mathrm{N}$ concentration in the nutrient solution, the lowest leaf number at the end of the growing cycle was recorded in 'Coral Queen' (Table 2).

Total leaf area (LA) and plant GI of 'Glamour Red' increased linearly and quadratically in response to an increase of the $\mathrm{N}$ concentration in the nutrient solution, while a linear increase was observed in 'Coral Prince', 'Coral Queen', 'Northern Light Red', and 'White peacock' $(\mathrm{N} \times \mathrm{G}$ interaction, data not shown). When averaged over cultivar, the quality index values of ornamental cabbage cultivated at $0.5,2.5,5,10$, and $20 \mathrm{mM} \mathrm{NO}_{3}{ }^{-}$were $1.5,2.8,3.5,5.0$, and 4.0 , respectively. Moreover, a positive linear correlation $\left(r=0.96^{* *}\right)$ was observed between SDW and quality index.

Leaf pigment content, SPAD index, and fluorescence measurement. No significant differences among treatments were observed for the total chlorophyll (average 618.7 $\mu \mathrm{g} \cdot \mathrm{g}^{-1}$ fresh weight) and carotenoids contents (average $85.6 \mu \mathrm{g} \cdot \mathrm{g}^{-1}$ fresh weight). Increasing the nitrate concentration from 0.5 to 20 mM caused linear and quadratical increases in the SPAD values, whereas only a quadratical increasing was observed for the maximum quantum use efficiency of PSII measured as the $F_{v} / F_{m}$ ratio (Table 3 ). Moreover, when averaged over the $\mathrm{N}$ concentration, the SPAD index decreased with cultivars in the following order: Northern Lights Red > Coral Queen $>$ Coral Prince $>$ Glamour Red $=$ White Peacock (Table 3).

Mineral composition. The macronutrient and iron concentrations as influenced by $\mathrm{N}$ level and cultivar treatments are displayed in Table 4. The concentration of $\mathrm{N}$ in leaves increased linearly and quadratically with the increase of nitrate level in the nutrient solution. Moreover, increasing the nitrate concentration in the nutrient solution from 0.5 to $20 \mathrm{~mm}$ caused quadratical increases of $\mathrm{P}, \mathrm{K}$, and $\mathrm{Fe}$ concentrations, whereas the concentrations of the two bivalent cations (i.e., $\mathrm{Ca}^{2+}$ and $\mathrm{Mg}^{2+}$ ) increased linearly. Irrespective of $\mathrm{N}$ concentration, the lowest $\mathrm{N}$ and Fe concentrations were observed in 'Coral Queen', whereas the lowest concentrations of $\mathrm{Ca}$ and $\mathrm{Mg}$ were recorded in 'Northern Lights Red' (Table 4).

\section{Discussion}

Optimizing of $\mathrm{N}$ fertilizer is essential for producing high-quality ornamental plants 
Table 1. Kinetic parameters of the shoot dry weight (SDW) (grams/plant) response curve of ornamental cabbage cultivars to nitrate concentration in the nutrient solution. Coefficient of determination $\left(R^{2}\right)$ and standard error of estimate (SEE) of the various response curves are also reported.

\begin{tabular}{lcccc}
\hline & \multicolumn{4}{c}{ SDW response curve } \\
\cline { 2 - 5 } Cultivar & $\alpha$ & $\beta$ & $R^{2}$ & SEE \\
\hline Coral Prince & $14.1 \mathrm{a}^{\mathrm{z}}$ & $5.5 \mathrm{a}$ & 0.955 & 0.918 \\
Coral Queen & $14.1 \mathrm{a}$ & $4.7 \mathrm{ab}$ & 0.953 & 0.991 \\
Glamour Red & $11.7 \mathrm{~b}$ & $3.3 \mathrm{bc}$ & 0.800 & 1.783 \\
Northern Lights Red & $9.8 \mathrm{~b}$ & $2.9 \mathrm{c}$ & 0.958 & 0.609 \\
White Peacock & $16.3 \mathrm{a}$ & $4.3 \mathrm{~b}$ & 0.951 & 1.154 \\
\hline
\end{tabular}

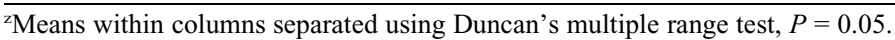

Table 2. Effects of nitrate concentration and cultivar on leaf number, final leaf area, shoot dry weight (SDW), and growth index (GI) of ornamental cabbage plants at the end of the experiment.

\begin{tabular}{|c|c|c|c|c|}
\hline Treatment & $\begin{array}{l}\text { Leaf number } \\
\text { (no. plant) }\end{array}$ & $\begin{array}{c}\text { Leaf area } \\
\left(\mathrm{cm}^{2} / \text { plant }\right)\end{array}$ & $\begin{array}{c}\text { SDW } \\
\text { (g/plant) }\end{array}$ & $\begin{array}{c}\text { GI } \\
\left(\mathrm{cm}^{3} / \text { plant }\right)\end{array}$ \\
\hline \multicolumn{5}{|l|}{$\overline{\text { Nitrogen }\left(\mathrm{mM} \mathrm{NO}_{3}{ }^{-}\right)}$} \\
\hline 0.5 & 13.9 & 319.6 & 2.2 & $4,759.1$ \\
\hline 2.5 & 16.9 & 717.1 & 4.7 & $9,339.5$ \\
\hline 5 & 18.8 & $1,261.3$ & 6.4 & $19,283.2$ \\
\hline 10 & 22.5 & $2,622.9$ & 10.6 & $31,571.8$ \\
\hline 20 & 22.4 & $2,638.1$ & 10.4 & $36,192.8$ \\
\hline \multicolumn{5}{|l|}{ Cultivar } \\
\hline Coral Prince & $19.4 \mathrm{a}^{\mathrm{z}}$ & $1,527.9$ & $6.6 \mathrm{~b}$ & $22,540.4 \mathrm{~b}$ \\
\hline Coral Queen & $17.3 \mathrm{~b}$ & $1,507.5$ & $7.0 \mathrm{~b}$ & $25,008.3 \mathrm{~b}$ \\
\hline Glamour Red & $19.7 \mathrm{a}$ & $1,496.0$ & $6.6 \mathrm{~b}$ & $13,119.8 \mathrm{c}$ \\
\hline Northern Lights Red & $19.0 \mathrm{a}$ & $1,429.3$ & $5.7 \mathrm{c}$ & $10,641.1 \mathrm{c}$ \\
\hline White Peacock & $19.2 \mathrm{a}$ & $1,598.3$ & $8.4 \mathrm{a}$ & $29,836.9 \mathrm{a}$ \\
\hline \multicolumn{5}{|l|}{ Significance $^{\mathrm{y}}$} \\
\hline Nitrogen $(\mathrm{N})$ & $* * *$ & $* * *$ & $* * *$ & $* * *$ \\
\hline Linear $\left(\mathrm{N}_{\mathrm{L}}\right)$ & $* * *$ & $*$ & $* * *$ & $* *$ \\
\hline Quadratic $\left(\mathrm{N}_{\mathrm{Q}}\right)$ & NS & $* * *$ & $* *$ & NS \\
\hline Cultivar & $* *$ & NS & $* *$ & $* * *$ \\
\hline $\mathrm{N} \times \mathrm{C}$ & NS & NS & $* *$ & $* * *$ \\
\hline $\mathrm{N}_{\mathrm{L}} \times \mathrm{C}$ & NS & NS & $* * *$ & $* * *$ \\
\hline $\mathrm{N}_{\mathrm{Q}} \times \mathrm{C}$ & NS & NS & $*$ & $*$ \\
\hline
\end{tabular}

${ }^{\mathrm{z}}$ Means within columns separated using Duncan's multiple range test, $P=0.05$.

${ }^{\mathrm{y}} \mathrm{L}=$ Linear; $\mathrm{Q}=$ Quadratic; $\mathrm{NS},{ }^{*}, * *, * * *$ Nonsignificant or significant at $P<0.05,0.01$, and 0.001 , respectively.

Table 3. Effects of nitrate concentration and cultivar on SPAD index, total chlorophyll and carotenoid contents $\left(\mu \mathrm{g} \cdot \mathrm{g}^{-1} \mathrm{FW}\right)$, and maximum quantum use of PSII in dark-adapted state $\left(\mathrm{F}_{\mathrm{v}} / \mathrm{F}_{\mathrm{m}}\right)$ of ornamental cabbage plants.

\begin{tabular}{|c|c|c|c|c|}
\hline Treatment & SPAD index & Chlorophyll & Carotenoids & $\mathrm{F}_{\mathrm{v}} / \mathrm{F}_{\mathrm{m}}$ \\
\hline \multicolumn{5}{|l|}{$\overline{\text { Nitrogen }\left(\mathrm{mM} \mathrm{NO}_{3}{ }^{-}\right)}$} \\
\hline 0.5 & 35.9 & 575.3 & 78.4 & 0.76 \\
\hline 2.5 & 42.2 & 586.1 & 81.2 & 0.83 \\
\hline 5 & 44.0 & 698.7 & 100.3 & 0.85 \\
\hline 10 & 43.8 & 594.4 & 80.4 & 0.85 \\
\hline 20 & 40.5 & 639.3 & 87.8 & 0.84 \\
\hline \multicolumn{5}{|l|}{ Cultivar } \\
\hline Coral Prince & $40.0 \mathrm{c}^{\mathrm{z}}$ & 608.5 & 81.2 & 0.82 \\
\hline Coral Queen & $42.2 \mathrm{~b}$ & 633.2 & 85.4 & 0.83 \\
\hline Glamour Red & $37.6 \mathrm{~d}$ & 603.1 & 88.3 & 0.82 \\
\hline Northern Lights Red & $49.4 \mathrm{a}$ & 665.8 & 97.3 & 0.84 \\
\hline White Peacock & $37.1 \mathrm{~d}$ & 582.9 & 75.9 & 0.83 \\
\hline \multicolumn{5}{|l|}{ Significance $^{y}$} \\
\hline Nitrogen $(\mathrm{N})$ & $* * *$ & NS & NS & $*$ \\
\hline Linear $\left(\mathrm{N}_{\mathrm{L}}\right)$ & $* * *$ & NS & NS & NS \\
\hline Quadratic $\left(\mathrm{N}_{\mathrm{Q}}\right)$ & $* *$ & NS & NS & $*$ \\
\hline Cultivar & $* *$ & NS & NS & NS \\
\hline $\mathrm{N} \times \mathrm{C}$ & NS & NS & NS & NS \\
\hline $\mathrm{N}_{\mathrm{L}} \times \mathrm{C}$ & NS & NS & NS & NS \\
\hline $\mathrm{N}_{\mathrm{Q}} \times \mathrm{C}$ & NS & NS & NS & NS \\
\hline
\end{tabular}

${ }^{\mathrm{z}}$ Means within columns separated using Duncan's multiple range test, $P=0.05$.

${ }^{\mathrm{y}} \mathrm{L}=$ Linear; $\mathrm{Q}=$ Quadratic; $\mathrm{NS}, *, * *, * * *$ Nonsignificant or significant at $P<0.05,0.01$, and 0.001 , respectively.

(Wilson et al., 2010). Ornamental cabbage growth parameters were very responsive to $\mathrm{N}$ concentration. For instance, the leaf number and GI increased linearly with increasing $\mathrm{N}$ concentration while the final leaf area and the SDW increased especially quadratically with increasing $\mathrm{N}$ concentration up to $10 \mathrm{~mm}$, reaching a plateau, thereafter, showing luxury consumption of the nutrient at $20 \mathrm{~mm}$. This was consistent with the findings of Mak and Yeh (2001) and Kent and Reed (1996) who observed that the optimum $\mathrm{N}$ fertilization rate for some bedding plants like New Guinea impatiens 'Barbados' (Impatiens ×hawker), and peace lilly cvs. 'Petite' and 'Sensation' (Spathiphyllum Schott) ranged between 8 and $10 \mathrm{~mm}$, whereas shoot growth declined more gradually above $10 \mathrm{~mm} \mathrm{~N}$, reaching $-50 \%$ at $30 \mathrm{~mm}$ N. Similarly, Gamrod and Scoggins (2006) demonstrated that the largest plants of persian shield (Strobilanthes dyerianus Mast.), based on leaf area and SDW, were produced with 300 $\mathrm{mg} \cdot \mathrm{L}^{-1}$; above this concentration (i.e., 400 $\mathrm{mg} \cdot \mathrm{L}^{-1}$ ) the plant shows a luxury consumption. Finally, Dole et al. (1994) found that Poinsettia (Euphorbia pulcherrima Willd. Ex. Klotzsch) grew most rapidly at 175 $\mathrm{mg} \cdot \mathrm{L}^{-1}$, and growth declined at higher fertilizer rates. Evaluation of the quality index of plant material at the end of the growing cycle indicates an optimal concentration of $10 \mathrm{~mm}$, whereas ornamental cabbage grown at $<2.5 \mathrm{mM} \mathrm{NO}_{3}{ }^{-}$negatively affected the aesthetic quality of the plants. Moreover, the GI increased linearly as nitrate concentration increased with the highest values recorded at 10 and especially at $20 \mathrm{~mm}$.

The functional relationship between the SDW and the nitrate concentration of the nutrient solution (from 0.5 to $20 \mathrm{~mm}$ ) using the Michaelis-Menten equation, allows ornamental cabbage cultivars to be discriminated according to their NUE by the estimate of $\alpha$ and $\beta$ indices. In agreement with Sorgonà et al. (2006), Colla et al. (2010, 2011) ornamental cabbage cultivars showed that the SDW response curves to increasing nitrate availability were best described by a nonlinear function, where shoot biomass increased with the increase in nutrientsolution nitrate level up to a plateau that indicated the genetic potential of the various cultivars (Fig. 1). In the current experiment, $\alpha$ values of SDW were significantly different, showing differences in genetic potential among the five cultivars. 'Coral Prince', 'Coral Queen', and 'White Peacock' exhibited the highest $\alpha_{\mathrm{s}}$ value (more vigorous cultivars), whereas 'Glamour Red' and 'Northern Lights Red' had the lowest values (less vigorous cultivars). The "equivalent yield/growth" of genotypes when the nutrients are nonlimiting are essential to design the crop as nutrient efficient or inefficient (Gourley et al., 1994). Assuming this principle, 'White Peacock' and 'Northern Lights Red' could be considered efficient in nitrate use (low $\beta$ ) among the more and less vigorous cultivars, respectively. The variation for NUE between cultivars could be expected because the genotypes affect both the use of absorbed $\mathrm{N}$ and the $\mathrm{N}$ uptake since each cultivar has its own morphological and functional characteristics for leaves and roots (Schenk, 2006; Thorup-Kristensen and Van der Boogard, 1999).

The SPAD measurements (foliar greenness) showed a similar trend to the SDW with 
Table 4. Effects of nitrate concentration and cultivar on macronutrients $\left(\mathrm{mg} \cdot \mathrm{g}^{-1} \mathrm{DW}\right)$ and iron $\left(\mu \mathrm{g} \cdot \mathrm{g}^{-1} \mathrm{DW}\right)$ in leaves of ornamental cabbage plants.

\begin{tabular}{|c|c|c|c|c|c|c|}
\hline Treatment & $\mathrm{N}$ & $\mathrm{P}$ & $\mathrm{K}$ & $\mathrm{Ca}$ & $\mathrm{Mg}$ & $\mathrm{Fe}$ \\
\hline \multicolumn{7}{|l|}{$\overline{\text { Nitrogen }\left(\mathrm{mM} \mathrm{NO}_{3}{ }^{-}\right)}$} \\
\hline 0.5 & 20.7 & 5.2 & 28.5 & 19.2 & 2.5 & 18.5 \\
\hline 2.5 & 27.9 & 10.4 & 29.9 & 25.1 & 3.0 & 19.0 \\
\hline 5 & 36.5 & 7.4 & 35.5 & 25.4 & 2.9 & 23.0 \\
\hline 10 & 43.7 & 11.0 & 32.0 & 33.2 & 3.5 & 20.0 \\
\hline 20 & 43.2 & 8.7 & 28.7 & 34.1 & 3.6 & 17.2 \\
\hline \multicolumn{7}{|l|}{ Cultivar } \\
\hline Coral Prince & $36.7 \mathrm{a}^{\mathrm{z}}$ & 8.5 & 32.4 & $29.3 \mathrm{a}$ & $3.3 \mathrm{ab}$ & $20.4 \mathrm{ab}$ \\
\hline Coral Queen & $31.5 \mathrm{~b}$ & 9.4 & 31.4 & $28.2 \mathrm{a}$ & $3.1 \mathrm{bc}$ & $18.2 \mathrm{~b}$ \\
\hline Glamour Red & $32.7 \mathrm{ab}$ & 8.3 & 31.0 & $26.7 \mathrm{ab}$ & $2.8 \mathrm{~cd}$ & $20.2 \mathrm{ab}$ \\
\hline Northern Lights Red & $35.0 \mathrm{ab}$ & 9.4 & 30.1 & $24.8 \mathrm{~b}$ & $2.7 \mathrm{~d}$ & $20.5 \mathrm{a}$ \\
\hline White Peacock & $36.1 \mathrm{a}$ & 7.1 & 29.8 & $28.0 \mathrm{a}$ & $3.5 \mathrm{a}$ & $18.4 \mathrm{ab}$ \\
\hline \multicolumn{7}{|l|}{ Significance $^{\mathrm{y}}$} \\
\hline Nitrogen $(\mathrm{N})$ & $* * *$ & $* * *$ & $* * *$ & $* * *$ & $* * *$ & $* * *$ \\
\hline Linear $\left(\mathrm{N}_{\mathrm{L}}\right)$ & $* * *$ & NS & NS & $* * *$ & $* * *$ & NS \\
\hline Quadratic $\left(\mathrm{N}_{\mathrm{Q}}\right)$ & $*$ & * & $* * *$ & NS & NS & $* * *$ \\
\hline Cultivar & * & NS & NS & * & $* * *$ & * \\
\hline $\mathrm{N} \times \mathrm{C}$ & NS & NS & NS & NS & NS & NS \\
\hline $\mathrm{N}_{\mathrm{L}} \times \mathrm{C}$ & NS & NS & NS & NS & NS & NS \\
\hline $\mathrm{N}_{\mathrm{Q}} \times \mathrm{C}$ & NS & NS & NS & NS & NS & NS \\
\hline
\end{tabular}

${ }^{\mathrm{z}}$ Means within columns separated using Duncan's multiple range test, $P=0.05$.

${ }^{\mathrm{y}} \mathrm{L}=$ Linear; $\mathrm{Q}=$ Quadratic; NS, *,**,***Nonsignificant or significant at $P<0.05,0.01$, and 0.001 , respectively.

respect to nitrate concentration in the nutrient solution. The SPAD values increased mostly linearly indicating that ornamental cabbage cultivars were able to accumulate chlorophyll in leaves by increasing $\mathrm{N}$ concentration in the nutrient solution. Ornamental cabbage cultivars exhibited a variation of leaf SPAD index as results of different genetic capability to synthesize chlorophyll and other pigments. Similarly to the SPAD index, the $F_{v} / F_{m}$ that is used as an indicator for the degree of photoinhibition in PSII (van Kooten and Snel, 1990) decreased under $\mathrm{N}$ deficiency. $\mathrm{N}$ stress likely decreases the capacity of protein synthesis, photo damaged PSII centers could not be repaired sufficiently, and consequently photoinhibition would occur (Godde and Hefer, 1994; Lima et al., 1999).

Leaf $\mathrm{N}$ concentration increased dramatically with increasing $\mathrm{N}$ levels. Ornamental cabbage plants supplied with 5 to $20 \mathrm{~mm}$ $\mathrm{NO}_{3}{ }^{-}$had leaf concentration ranging from 36.5 to $43.7 \mathrm{mg} \cdot \mathrm{g}^{-1}$ as recommended for ornamental cabbage and kale (35.0-45.0 $\mathrm{mg} \cdot \mathrm{g}^{-1}$; Whipker et al., 1998). Similarly, the $\mathrm{P}, \mathrm{K}, \mathrm{Ca}$, and $\mathrm{Mg}$ concentrations increased with increasing nitrate level from 0 to $20 \mathrm{~mm}$ with the highest values recorded above $10 \mathrm{~mm}$. Moreover, the leaf macronutrient concentrations in all treatments were within the optimum ranges as recommended by Whipker et al. (1998). Finally, tissue nutrient concentrations varied greatly among the cultivars indicating variation in nutrient requirements (Whipker et al., 1998). 'Coral Queen' showed the lowest leaf concentration of $\mathrm{N}$ and $\mathrm{Fe}$, whereas the lowest leaf concentration of bivalent cations ( $\mathrm{Ca}$ and $\mathrm{Mg}$ ) was recorded in 'Northern Lights Red'.

\section{Conclusions}

The progressive application of nitrate in the nutrient solution from 0.5 to $20 \mathrm{~mm}$ significantly affected the growth and plant quality of ornamental cabbage. Leaf number, leaf area, SPAD index, $\mathrm{F}_{\mathrm{v}} / \mathrm{F}_{\mathrm{m}}$, and SDW increased with increasing nitrate concentration up to $10 \mathrm{~mm}$, reaching a plateau, showing luxury consumption of nitrate at $20 \mathrm{~mm}$. The results also indicated that the selection of plant cultivars having a low $\mathrm{N}$ requirement is important to increase NUE. 'Northern Lights Red' needed less $\mathrm{NO}_{3}{ }^{-}$in the nutrient solution to reach half maximum SDW, and could be considered the highest nitrate efficient cultivar. However, 'White Peacock' was the most efficient cultivar in $\mathrm{N}$ use (lower $\beta$ value) among the more vigorous cultivars (Coral Prince, Coral Queen, and White Peacock).

\section{Literature Cited}

Arena, C., L. Vitale, and A. Virzo De Santo. 2005. Photosynthetic response of Quercus ilex L. plants grown on compost and exposed to increasing photon flux densities and elevated $\mathrm{CO}_{2}$. Photosynthetica 43:615-619.

Benincasa, P., M. Guiducci, and F. Tei. 2011. The nitrate use efficiency: Meaning and sources of variation-case studies on three vegetable crops in central Italy. HortTechnology 21: 266-272.

Bremner, J.M. 1965. Total nitrogen, p. 1149-1178. In: Black, C.A., D.D. Evans, I.L. White, L.E. Ensminger, F.E. Clark (eds.). Methods of soil analysis, Part 2.

Colla, G., C.M. Cardona-Saurez, M. Cardarelli, and Y. Rouphael. 2010. Improving nitrogen use efficiency in melon by grafting. HortScience 45:559-565.

Colla, G., Y. Rouphael, C. Mirabelli, and M. Cardarelli. 2011. Nitrogen-use efficiency traits of mini-watermelon in response to grafting and nitrate-fertilization rates. J. Plant Nutr. Soil Sci. 174:933-941.

Dole, J.M., J.C. Cole, and S.L. von Broembsen. 1994. Growth of poinsettias, nutrient leaching, and water use efficiency respond to irrigation methods. HortScience 29:858-864.
Gamrod, E.E. and H.L. Scoggins. 2006. Fertilizer concentration affects growth and foliar elemental concentration of Strobilanthes dyerianus. HortScience 41:231-234.

Gerendás, J., J. Abbadi, and B. Sattelmacher. 2008. Potassium efficiency of safflower (Carthamus tinctorius L.) and sunflower (Helianhus annuus L.). J. Plant Nutr. Soil Sci. 171:431-439.

Gibson, J.L. and B.E. Whipker. 2003. Ornamental cabbage quality improved by continual fertilizations through center-head coloration. HortScience 38:1381-1384

Glass, A.D.M. 2003. Nitrogen use efficiency of crop plants: Physiological constraints upon nitrate absorption. Crit. Rev. Plant Sci. 22: 453-470.

Godde, D. and M. Hefer. 1994. Photoinhibition and light-dependent turnover of the D1 reactioncentre polypeptide of photosystem II are enhanced by mineral-stress conditions. Planta 193:290-299.

Gomez, K.A. and A.A. Gomez. 1983. Comparison between treatment means, p. 187-240. In: Gomez, K.A. and A.A Gomez (eds.). Statistical Procedures for Agricultural Research. 2nd ed. Wiley, NY.

Gourley, C.J.P., D.L. Allan, and M.P. Russelle. 1994. Plant nutrient efficiency: A comparison and suggested improvement. Plant Soil 158: 29-37.

Hirsch, R. and M. Sussman. 1999. Improving nutrient capture from soil by genetic manipulation of crop plants. Rends Biotechnol. 17:356-361.

Karla, Y.P. 1998. Handbook of reference methods for plant analysis. CRC Press, Boca Raton, FL.

Kent, M.W. and D.W. Reed. 1996. Nitrogen nutrition of New Guinea impatiens 'Barbados' and Spathiphyllum 'Petite' in a subirrigation system. J. Amer. Soc. Hort. Sci. 121:816-819.

Kushad, M.M., R. Cloyd, and M. Babadoost. 2004. Distribution of glucosinolates in ornamental cabbage and kale cultivars. Sci. Hort. 101:215221.

Lemaire, G. and F. Gastal. 1997. N uptake and distribution in plant canopies, p. 3-43. In: Lemaire, G. (ed.). Diagnosis on the Nitrogen status in crops. Springer-Verlag, Heidelberg, Germany.

Lichtenthaler, H.K. and A.R. Wellburn. 1983. Determinations of total carotenoids and chlorophylls $a$ and $b$ of leaf extracts in different solvents. Proc. of the Bioch. Soc. Trans. 603rd Mtg., Liverpool, United Kingdom, Vol. 11:591592.

Lima, J.D., P.R. Mosquim, and F.M. Da Matta. 1999. Leaf gas exchange and chlorophyll fluorescence parameters in Phaseolus vulgaris as affected by nitrogen and phosphorus deficiency. Photosynthetica 37:113-121.

Lynch, J.P. 1998. The role of nutrient-efficient crops in modern agriculture. J. Crop Prod. $1: 241-264$.

MacDonald, W.N., T.J. Blom, M.J. Tsujita, and B. J. Shelp. 2013. Review: Improving nitrogen use efficiency of potted chrysanthemum: Strategies and benefits. Can. J. Plant Sci. 93:1009-1016.

Mak, A.T.Y. and D.M. Yeh. 2001. Nitrogen nutrition of Spathiphyllum 'sensation' grown in sphagnum peat- and coir-based media with two irrigation methods. HortScience 36:645649.

Marschner, H. 2002. Mineral nutrition of higher plants. 3rd ed. Academic Press, London.

Martinez, V., F.M. Del Amor, and L.F.M. Marcelis. 2005. Growth and physiological response of tomato plants to different periods of nitrogen starvation and recovery. J. Hort. Sci. Biotechnol. 80:147-153. 
Norrie, J., M.E.D. Graham, and A. Gosselin. 1994. Potential evapotranspiration as a means of predicting irrigation timing in greenhouse tomatoes grown in peat bags. J. Amer. Soc. Hort. Sci. 119:163-168.

Rathke, G.W., T. Behrens, and W. Diepenbrock. 2006. Integrated nitrogen management strategies to improve seed yield, oil content and nitrogen efficiency of winter oilseed rape. Agr. Ecosyst. Environ. 117:80-108.

Roberts, T.L. 2008. Improving nutrient use efficiency. Turk. J. Agr. For. 32:177-182.

Rouphael, Y., M. Cardarelli, E. Rea, and G. Colla. 2008. The influence of irrigation system and nutrient solution concentration on potted geranium production under various conditions of radiation and temperature. Sci. Hort. 118:328-337.

Rouphael, Y. and G. Colla. 2005a. Growth, yield, fruit quality and nutrient uptake of hydroponically cultivated zucchini squash as affected by irrigation systems and growing seasons. Sci. Hort. 105:177-195.

Rouphael, Y. and G. Colla. 2005b. Radiation and water use efficiencies of greenhouse zucchini squash in relation to different climate parameters. Eur. J. Agron. 23:183-194.

Rouphael, Y. and G. Colla. 2009. The influence of drip-irrigation or subirrigation on zucchini squash grown in closed-loop substrate culture with high and low nutrient solution concentrations. HortScience 44:306-311.

Rouphael, Y., G. Colla, A. Battistelli, S. Moscatello, S. Proietti, and E. Rea. 2004. Yield, water requirement, nutrient uptake and fruit quality of zucchini squash grown in soil and soilless culture. J. Hort. Sci. Biotechnol. 79:423-430.

Schenk, M.K. 2006. Nutrient efficiency of vegetable crops. Acta Hort. 700:25-38.

Sorgonà, A., M.R. Abenavoli, P.G. Gringeri, and G. Cacco. 2006. A comparison of nitrogen use efficiency definitions in Citrus rootstocks. Sci. Hort. 109:389-393.

Thorup-Kristensen, K. and R. Van der Boogard. 1999. Vertical and horizontal development of the root system of carrots following green manure. Plant Soil 212:145-153.

van Kooten, O. and J.F.H. Snel. 1990. The use of chlorophyll fluorescence nomenclature in plant stress physiology. Photosynth. Res. 25:147-150.

Whipker, B.E., J.L. Gibson, R.A. Cloyd, C.R. Campbell, and R. Jones. 1998. Success with ornamental cabbage and kale. NCSU Hort. Info. Lflt. No. 507.9 p.

Wilson, C., J. Albona, M. Mozdzen, and C. Riiska. 2010. Irrigation water and nitrate-nitrogen loss characterization in southern Florida nurseries: Cumulative volumes, runoff rates, nitratenitrogen concentrations and loadings, and implications for management. HortTechnology 20:325-330. 